\title{
Soil pH, exchangeable aluminium and lucerne yield responses to lime in a South Island high country soil
}

\author{
J. L. MOIR ${ }^{1}$ and D. J. MOOT ${ }^{1}$ \\ ${ }^{I}$ Faculty of Agriculture and Life Sciences \\ Lincoln University, Canterbury \\ jim.moir@lincoln.ac.nz
}

\begin{abstract}
A 2-year field experiment was conducted on a high country brown stony soil in the Lees Valley, North Canterbury. Two forms of lime ('AgLime' and 'Quicklime') were applied at 4 rates $(0,2,4$ and $8 \mathrm{t}$ / ha) and plots sown with 'Grasslands Kaituna' lucerne. Soil $\mathrm{pH}$ was strongly $\left(\mathrm{R}^{2}=0.73\right)$ related to exchangeable aluminium (Al), with a sharp rise in plant-available Al levels below a $\mathrm{pH}$ of 5.8. Soil $\mathrm{pH}$ changes of 0.15 units/t lime applied in the $0-7.5 \mathrm{~cm}$ horizon, and lower, variable, $\mathrm{pH}$ changes in the $7.5-15$ and $15-30 \mathrm{~cm}$ horizons were achieved. Soil exchangeable Al dropped to low levels $(<0.3 \mathrm{me} / 100 \mathrm{~g})$ at all liming rates in the $0-7.5 \mathrm{~cm}$ soil horizon, and had a moderate to low effect in deeper soil horizons. Increases in soil exchangeable Al below soil $\mathrm{pH} 5.8$ were linear, increasing at $0.2 \mathrm{me}$ $\mathrm{Al} / 100 \mathrm{~g}$ per $0.1 \mathrm{pH}$ unit decrease in soil $\mathrm{pH}$. Effects of lime form were unclear. Lucerne yields were often low, in the order of 700-1 $200 \mathrm{~kg} \mathrm{DM} / \mathrm{ha}$, and were not influenced by lime rates or soil exchangeable Al. Other, soil and climate variables are discussed in relation to current DM yields. Measurements at this site are ongoing.
\end{abstract}

Keywords: alfalfa, lucerne, lime, soil pH, dry matter yield, climate

\section{Introduction}

The productivity of South Island hill country is typified by a short, often soil moisture limited growing season. Alternative pasture species have been suggested to improve dryland pasture production (Brown et al. 2003; McGowan et al. 2003), and moreover, the deep-rooting nature of lucerne (Medicago sativa) has highlighted this species for dryland environments (Brown et al. 2009; Thomas 2003). However, lucerne is intolerant of acid soil conditions, and related aluminium (Al) toxicity (Rechcigl et al. 1988; Su \& Evans 1996).

On about 500000 ha of farmed high country, soils have low soil $\mathrm{pH}$ and possibly high soil Al. Soil acidity (low soil $\mathrm{pH}$ coupled with toxic levels of soil aluminium) and low available phosphorus (P) and sulphur (S) may also limit establishment and maintenance of legumes (Moir et al. 2000; Haynes \& Williams 1993). To offset increased soil acidity, lime must be applied, and where this cannot be done, soils may be too acidic for legumes and productivity declines sharply (Edmeades et al. 1983; Lanyon \& Griffith 1988). Often the cost of lime is uneconomic in extensive high country, and the response to liming unknown. The relationship between pasture production and soil $\mathrm{pH}$ is well established on some soils and the critical level of soil Al (Haynes \& Williams 1993) and the relative Al tolerance of some forage legumes have also been examined (Edmeades $e t$ al. 1991; Wheeler et al. 1992). However, studies of soil $\mathrm{pH}$ changes with liming, and associated changes in soil exchangeable Al, in South Island high country soils are scarce.

A previous experiment on this site showed poor lucerne yields, and problems with seedling establishment (Lewis 2007). Evidence of horizontal, restricted, root growth suggests soil acidity, and related toxicity issues. This paper summarises results from a field experiment, that examined the effects of lime rate and type on soil exchangeable aluminium levels down the profile of an acid high country soil.

\section{Methods}

\section{Site description and trial design}

The field study at Mt Pember Station in the Lees Valley, North Canterbury, is on a high country brown stony soil (New Zealand classification: High Country Brown shallow stony soil; USDA classification: Inceptisol). The altitude is 430 m.a.s.l. with annual rainfall of $600 \mathrm{~mm}$. Further details of the trial site were given by Fasi et al. (2008) where forage crops had been grown, and where soil fertility was $\mathrm{pH} 5.3$, Olsen P $12 \mu \mathrm{gP} /$ $\mathrm{mL}$ and sulphate $\mathrm{S} 8 \mu \mathrm{gS} / \mathrm{g}$. The site was sprayed with glyphosate (3 L/ha; $540 \mathrm{~g}$ a.i./L) in February 2008 and plots marked out a month later. The trial consisted of $16,10 \times 20 \mathrm{~m}$ plots in a randomised design. Treatments were standard 'AgLime' $\left(\mathrm{CaCO}_{3}\right)$ or 'Quicklime' $(\mathrm{CaO})$, at 4 rates $(0,2,4$ and $8 \mathrm{t} / \mathrm{ha})$, in 2 replicates. Lime was surface applied in March 2008. Basal maintenance superphosphate $(300 \mathrm{~kg} / \mathrm{ha} ; 24 \mathrm{~kg} \mathrm{P}$ and $62 \mathrm{~kg} \mathrm{~S} / \mathrm{ha}$ ) was applied in September 2008. In October 2008 plots were soil sampled at $0-7.5,7.5-15$ and 15$30 \mathrm{~cm}$ depths $(25 \mathrm{~mm}$ diameter $\mathrm{x} 300 \mathrm{~mm}$ deep cores; 20 cores per plot, bulked). Where stones prevented 
coring, a trowel was used to obtain the deeper samples. Soil samples were analysed for $\mathrm{pH}$ (1:2.5 soil: water ratio) and exchangeable aluminium ( $1 \mathrm{M} \mathrm{KCl}$ extraction followed by ICP-OES analysis). The variability of soil $\mathrm{pH}$, soil $\mathrm{Al}$ and lucerne yield was analysed by analysis of variance (ANOVA) using GenStat 11.0 (Lawes Agricultural Trust, Rothamsted, UK). The model included lime type, lime rate, soil horizon depth and interactions as fixed effects.

\section{Crop sowing and trial management}

The site was re-sprayed with glyphosate (4 L/ha; 540 $\mathrm{g}$ a.i./L) in November 2008. 'Grasslands Kaituna' lucerne was direct-drilled at $14 \mathrm{~kg} / \mathrm{ha}$ of coated seed on $4^{\text {th }}$ December 2008. Emergence was measured on December $22^{\text {nd }}$ (cotyledon stage; 37 plants $\mathrm{m}^{2}$ ) from 2 $\mathrm{x} 1 \mathrm{~m}$ lengths of drill row per plot multiplied by the 15 $\mathrm{cm}$ row spacing. Lucerne dry matter (DM) yield was measured at regular intervals over 2 years on all plots using a 'pasture capacitance probe' (JenQuip, Fielding), calibrated to DM cuts at each measurement. Calibration cuts involved 20 probe readings across a range of stand heights of $0.2 \mathrm{~m}^{2}$ quadrats before cutting at $1-2 \mathrm{~cm}$ above the ground, drying and weighing. In March 2009 the trial site was 'grid sample' surveyed (20 points per plot) for topsoil depth (depth to gravel) using a metal spike with depth graduation. Climate (rainfall, air and soil temperature, topsoil moisture) was measured onsite using an automated weather station.

\section{Results}

\section{Soil pH and aluminium levels}

Over all soil sampling depths and liming rates, soil $\mathrm{pH}$ was strongly $\left(\mathrm{R}^{2}=0.73\right)$ associated with soil exchangeable Al levels (Fig. 1). A sigmoidal curve described the relationship. Soil exchangeable Al was low $(0.1-0.2 \mathrm{me} / 100 \mathrm{~g})$ within the soil $\mathrm{pH}$ range of 5.87.0. However, exchangeable Al levels rose sharply to $0.4 \mathrm{me} / 100 \mathrm{~g}$ when $\mathrm{pH}$ fell below 5.8. At a $\mathrm{pH}$ of 5.5, exchangeable $\mathrm{Al}$ increased to $1.0 \mathrm{me} / 100 \mathrm{~g}$, and values

Figure 1 The relationship between exchangeable soil aluminium and soil $\mathrm{pH}$ at Lees Valley, North Canterbury.

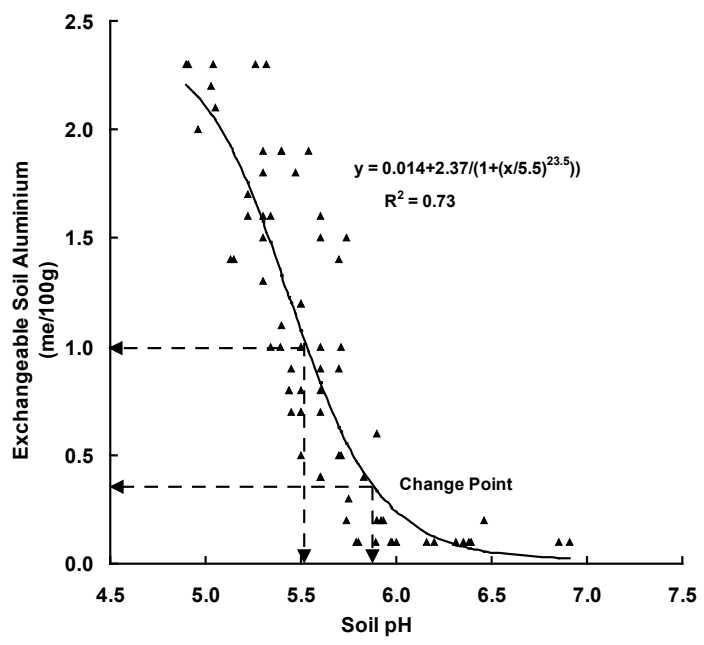

Table 1 Soil pH values for three soil horizons for 'AgLime' and 'Quicklime' treatments applied to soils at a trial site at Lees Valley, North Canterbury.

\begin{tabular}{lccccc}
\hline $\begin{array}{l}\text { Soil depth } \\
(\mathrm{cm})\end{array}$ & $\begin{array}{c}\text { Lime rate } \\
(\mathrm{t} / \mathrm{ha})\end{array}$ & Soil $\mathrm{pH}$ & 'AgLime' & \multicolumn{2}{c}{ 'Quicklime' } \\
\hline \multirow{3}{*}{$0-7.5$} & 0 & 5.4 & 0.9 & 5.5 & Soil Al \\
& 2 & 6.0 & 0.1 & 5.7 & 0.9 \\
& 4 & 5.9 & 0.2 & 6.1 & 0.1 \\
& 8 & 6.3 & 0.1 & 6.9 & 0.1 \\
\hline \multirow{3}{*}{15} & 0 & 5.3 & 1.3 & 5.2 & 1.4 \\
& 2 & 5.9 & 1.0 & 5.2 & 2.1 \\
& 4 & 5.6 & 0.6 & 5.7 & 1.7 \\
$15-30$ & 8 & 5.9 & 0.3 & 6.0 & 0.6 \\
& 0 & 5.3 & 2.0 & 5.2 & 1.7 \\
& 2 & 5.5 & 1.2 & 5.0 & 2.1 \\
\hline LSD $_{5 \%}$ & 4 & 5.4 & 1.4 & 5.7 & 1.2 \\
& 8 & 5.6 & 1.3 & 5.9 & 0.9 \\
\hline
\end{tabular}


Figure 2 Mean dry matter (DM) yields of lucerne crops on 19 March 2009, grown with different lime forms and rates in the Lees Valley, North Canterbury. Error bars represent 1 SEM.

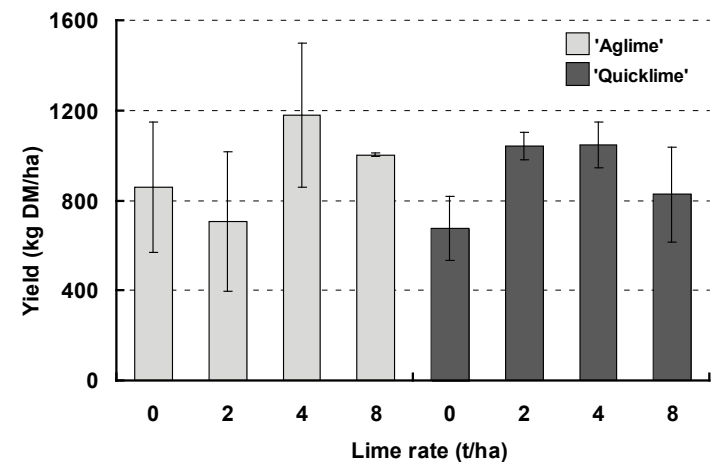

Figure 3 Relationship between maximum 'sub-plot' dry matter (DM) yield and topsoil depth (depth to gravel), of lucerne crops grown in the Lees Valley, North Canterbury.

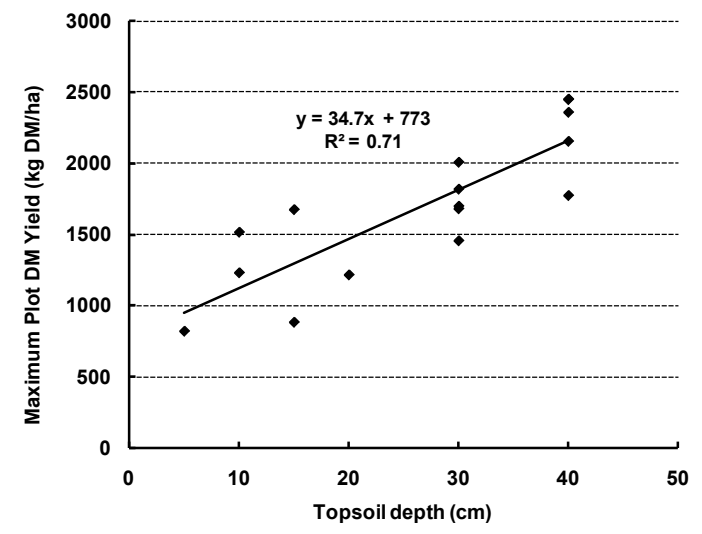

above 2.0 me $/ 100 \mathrm{~g}$ were measured at a $\mathrm{pH}$ of 5.0. Increases in exchangeable $\mathrm{Al}$ below $\mathrm{pH} 5.8$ were linear, increasing at $0.2 \mathrm{me} \mathrm{Al} / 100 \mathrm{~g}$ per $0.1 \mathrm{pH}$ unit decrease in $\mathrm{pH}$.

\section{Lime effects on soil $\mathrm{pH}$ and aluminium levels}

Soil $\mathrm{pH}$ differed with horizon depth $(\mathrm{P}<0.01)$ and lime rate $(\mathrm{P}<0.001)$, though lime type had no significant effect. Likewise, soil Al differed with horizon depth $(\mathrm{P}<0.01)$ and lime rate $(\mathrm{P}<0.05)$, with no difference between lime types. The unlimed $\mathrm{pH}(0-7.5 \mathrm{~cm}$ horizon $)$ was slightly lower and plant-available Al higher than in the subsoil horizons (Table 1). At the 'baseline' (unlimed) $\mathrm{pH}$ of 5.3-5.4, soil exchangeable Al levels were $0.9-2.0 \mathrm{me} / 100 \mathrm{~g}$. Liming increased $\mathrm{pH}$ and lowered plant-available $\mathrm{Al}$ at the surface $(0-7.5 \mathrm{~cm})$ soil horizon. Soil $\mathrm{pH}$ generally increased in a linear fashion in this horizon with increasing lime rate, to a maximum $\mathrm{pH}$ of 6.3 for 'AgLime' and 6.9 for 'Quicklime' (Table 1). Correspondingly, exchangeable Al levels were low $(0.1-0.2 \mathrm{me} / 100 \mathrm{~g})$ for all lime treatments in this horizon. Increases in $\mathrm{pH}$ resulting from liming were also linear in deeper horizons, though the $\mathrm{pH}$ shift was lower, and more variable. Exchangeable $\mathrm{Al}$ was in the medium to high range $(0.6-2.1 \mathrm{me} / 100 \mathrm{~g})$ in this horizon even after lime was applied at 2-4 t/ha.

Comparable but inconsistent $\mathrm{pH}$ changes occurred at the $15-30 \mathrm{~cm}$ depth, with soil Al remaining at moderately high levels in this horizon. 'Quicklime' appeared to have a greater effect on $\mathrm{pH}$ and exchangeable $\mathrm{Al}$ levels than 'AgLime' in this deeper horizon, but the data were variable. 'AgLime', at $8 \mathrm{t} / \mathrm{ha}$, increased $\mathrm{pH}$ from 5.3 to 5.6 in this horizon, and reduced exchangeable $\mathrm{Al}$ from 2.0 to $1.3 \mathrm{me} / 100 \mathrm{~g}$ (Table 1) compared with a pH increase from 5.2 to 5.9 and an $\mathrm{Al}$ reduction from 1.7 to $0.9 \mathrm{me} / 100 \mathrm{~g}$ for the 'Quicklime'.

\section{Lucerne yield}

Lucerne DM yield was low at this trial site, and not related to lime rate or product. Results from a 'typical' DM measurement are presented in Fig. 2. Yields ranged from 700-1 $200 \mathrm{~kg} \mathrm{DM} / \mathrm{ha}$ and were not affected by lime rate, $\mathrm{pH}$ or exchangeable Al. This suggests that factors other than lime were controlling plant yields. Lucerne yields did show some response at medium liming rates at some measurement times, though data were variable and require confirmation.

A preliminary survey of topsoil depth (depth to gravel) at the trial site indicated it is extremely variable, even over 1-2 m distances. Of all variables measured, lucerne yields were best explained $\left(\mathrm{R}^{2}=0.71\right.$; Fig. 3$)$ by topsoil depth when individual plots were split into four 'sub-plots'.

\section{Discussion}

The objective of this study was to determine the effects of liming on soil $\mathrm{pH}$, and in turn, on exchangeable $\mathrm{Al}$ and lucerne yield in South Island high country. A strong relationship between soil $\mathrm{pH}$ and exchangeable plantavailable Al was established for this soil, whereby soil exchangeable $\mathrm{Al}$ increased sharply below a soil $\mathrm{pH}$ of 5.8. This result generally agrees with that reported by Hochman et al. (1992) for three New Zealand Brown soils, but does not follow in soils of different age and mineralogy. For example, Mullen et al. (2006) reported low exchangeable $\mathrm{Al}$ of $0.4 \mathrm{me} / 100 \mathrm{~g}$ at $\mathrm{pH} 4.4\left(\mathrm{CaCl}_{2}\right)$ in a soil (Red Chromosol, granitic parent material) in NSW. Our results highlight the problem of higher soil-exchangeable plant-available aluminium levels (at 'common' field soil pHs) in brown soils, which are common to South Island high country. Also noteworthy, is the variable relationship between soil exchangeable $\mathrm{Al}$ and plant $\mathrm{Al}$ uptake, and that relationships between these indices are soil or site specific (Rechcigal et al. 
1988). Further studies are required to establish such relationships at this site.

Liming had a strong effect on soil $\mathrm{pH}$, especially in the $0-7.5 \mathrm{~cm}$ soil horizon, where $\mathrm{pH}$ increased an average of 0.15 units/t lime applied. This result agrees with Wheeler \& Edmeades (1995) and Black $\&$ Cameron (1984). Differences in the effect of lime product were not significant due to the variability of soil $\mathrm{pH}$ data. Liming reduced soil exchangeable $\mathrm{Al}$ levels in the surface soil horizon from 0.9 to $0.1-0.2$ $\mathrm{me} / 100 \mathrm{~g}$. This is an important result, and demonstrates that exchangeable $\mathrm{Al}$ at the soil surface can be reduced to safe levels, even at low liming rates. At a soil $\mathrm{pH}$ of 5.5, exchangeable $\mathrm{Al}$ increased to $1.0 \mathrm{me} / 100 \mathrm{~g}$ or above. At this level, exchangeable $\mathrm{Al}$ is likely to reduce DM yield (Wheeler et al. 1992).

The measurable effects of lime were less obvious in deeper soil horizons, with only modest changes in soil $\mathrm{pH}$ and exchangeable Al. Lime at $8 \mathrm{t} / \mathrm{ha}$ increased soil $\mathrm{pH}$ by about $0.5 \mathrm{pH}$ units in the 7.5-15 and 15-30 $\mathrm{cm}$ soil horizons. This increase in soil $\mathrm{pH}$ resulted in a corrresponding drop in exchangeable soil $\mathrm{Al}$ of around $1.0 \mathrm{me} / 100 \mathrm{~g}$ at the $8 \mathrm{t} / \mathrm{ha}$ lime rate to around 0.45 and $1.1 \mathrm{meAl} / 100 \mathrm{~g}$ for the $7.5-15$ and $15-30 \mathrm{~cm}$ soil horizons, respectively. The implication is that even at a rate of $8 \mathrm{t} / \mathrm{ha}$, surface-applied lime is unlikely to reduce plant-available soil aluminum to levels safe for lucerne growth in the short-term in this environment.

Lucerne growth, and therefore yield, has been restricted at this site. Yields were comparable to those of Mullen et al. (2006) and lower than those reported by McGowan et al. (2003), Teixeira et al. (2006) and Grewal \& Williams (2003). Any effects of liming, and associated soil exchangeable plant-available Al levels, have been confounded by other controlling factors. A survey of topsoil depth at this site revealed large differences over short distances. Further, the only indice which relates to our yield measurements, to date, was topsoil depth. Given that the finer textured topsoil sits over a very coarse gravel base of low readily (plant)available water holding capacity (RAWC), it is likely that variation in micro-topography, influencing topsoil depth, is strongly affecting plant yield by substantially increasing the RAWC of the deeper fine textured soil compared with an area with a shallow topsoil (Brown et al. 2003; 2009). The rainfall at this site is also low $(\approx 600 \mathrm{~mm} / \mathrm{yr})$, especially over summer. Therefore, the variable topsoil depth, in combination with a summerdry climate, appear to be the key factors driving lucerne yield. Yields do not appear to be related to $\mathrm{pH}$ and $\mathrm{Al}$ levels. However, this is an establishing crop, and any effect may become apparent over the next 12 months. This result reinforces the importance of running trials for longer time spans in order to report on the effects of climate and its variability. It is also possible that soil $\mathrm{pH}$ and exchangeable Al levels are in fact reducing lucerne rooting depth (observed visually), and therefore effective plant water availability. Further work is to assess the feasibility and economics of liming.

\section{Conclusions}

- Soil pH was strongly related to levels of soil plant-available aluminium.

- Surface applied lime increased soil $\mathrm{pH}$ and reduced soil plant-available aluminium.

- Liming was most effective at the soil surface and less effective at depth $(15-30 \mathrm{~cm})$.

- Higher rates of lime were more effective, though data were variable. No significant difference in effectiveness between 'AgLime' and 'Quicklime' was detected.

- Soil $\mathrm{pH}$ and $\mathrm{Al}$ levels were not related to lucerne yield. Extreme variability in depth of topsoil (micro-topography) and hence plant-available water storage have influenced yields.

\section{ACKNOWLEDGEMENTS}

The authors thank Vonny Fasi, Malcolm Smith, Keith Pollock, Dave Jack and Dan Dash for field assistance. This research was funded by the Ministry of Agriculture and Forestry (MAF) Sustainable Farming Fund (SSF; 09123).

\section{REFERENCES}

Black, A.S.; Cameron, K.C. 1984. Effect of leaching on soil properties and lucerne growth following lime and gypsum amendments to a soil with an acid subsoil. New Zealand Journal of Agricultural Research 27: 195-200.

Brown, H.E.; Moot, D.J.; Fletcher, A.L.; Jamieson, P.D. 2009. A framework for quantifying water extraction and water stress responses of perennial lucerne. Crop and Pasture Science 60: 785-794.

Brown, H.E.; Moot, D.J.; Pollock, K.M. 2003. Long term growth rates and water extraction patterns of dryland chicory, lucerne and red clover. Legumes for dryland pastures. Grassland Research and Practice Series 11: 91-99.

Edmeades, D.C.; Smart C.E.; Wheeler, D.M. 1983. Aluminium toxicity in New Zealand soils: preliminary results on the development of diagnostic criteria. New Zealand Journal of Agricultural Research 26: 493-501.

Edmeades, D.C.; Blamey, F.P.C.; Asher, C.J.; Edwards, D.G. 1991. Effects of $\mathrm{pH}$ and aluminium on the growth of temperate pasture species. II. Growth and nodulation of legumes. Australian Journal of Agricultural Research 42: 893-900. 
Fasi, V.; Mills, A.; Moot, D. J.; Scott, W. R.; Pollock, K. 2008. Comparative growth forms of dryland forage legumes. Proceedings of the New Zealand Grassland Association 70: 123-130.

Grewal, H.S.; Williams, R. 2003. Liming and cultivars affect root growth, nodulation, leaf to stem ratio, herbage yield, and elemental composition of alfalfa on an acid soil. Journal of Plant Nutrition 26: 16831696.

Haynes, R.J.; Williams, P.H. 1993. Nutrient cycling and soil fertility in the grazed pasture ecosystem. Advances in Agronomy 49: 120-199.

Hochman, Z.; Edmeades, D.C; White, E. 1992. Changes in effective cation exchange capacity and exchangeable aluminium with soil $\mathrm{pH}$ in limeamended field soils. Australian Journal of Soil Research 30: 177-187.

Lanyon, L.E.; Griffith, W.K. 1988. Nutrition and fertilizer use. pp. 333-372. In: Alfalfa and alfalfa improvement. Eds. Hanson, A.A.; Barnes, D.K.; Hill, R.R. American Society of Agronomy, Madison, USA.

Lewis, B. 2007. Understanding how sowing rate and date affect autumn lucerne establishment in Canterbury. Unpublished Bachelor of Agricultural Science Honours dissertation, Lincoln University, New Zealand.

McGowan, A.W.; Sheath, G.W.; Webby, R.W. 2003. Lucerne for high quality summer feed in North Island hill country. Legumes for dryland pastures. Grassland Research and Practice Series 11: 169-174.

Moir, J.L.; Scotter, D.R.; Hedley, M.J.; Mackay, A.D. 2000. A climate-driven, soil fertility dependent, pasture production model. New Zealand Journal of Agricultural Research 43: 491-500.
Mullen, C.L.; Scott, B.J.; Evans, C.M.; Conyers, M.K. 2006. Effect of soil acidity and liming on lucerne and following crops in central-western New South Wales. Australian Journal of Experimental Agriculture 46: 1291-1300.

Rechcigl, J.E.; Edmisten, K.L.; Wolf, D.D.; Renau, R.B. Jr. 1988. Response of alfalfa grown on acid soil to different chemical amendments. Agronomy Journal 80: 515-518.

Su, C.; Evans, L.J. 1996. Soil solution chemistry and alfalfa response to $\mathrm{CaCO}_{3}$ and $\mathrm{MgCO}_{3}$ on an acidic gleysol. Canadian Journal of Soil Science 76: 41-47.

Teixeira, E.I.; Moot, D.J.; Brown, H.E.; Fletcher, A.L. 2006. The dynamics of lucerne (Medicago sativa L.) yield components in response to defoliation frequency. European Journal of Agronomy 26: 394400.

Thomas, R.G. 2003. Comparative growth forms of dryland forage legumes. Legumes for dryland pastures. Grassland Research and Practice Series No.11: 19-25.

Wheeler, D.M.; Edmeades, D.C.; Christie, R.A.; Gardner, R. 1992. Effect of aluminium on the growth of 34 plant species: A summary of results obtained in low ionic strength solution culture. Plant and Soil 146: 61-66.

Wheeler, D.M.; Edmeades, D.C. 1995. Effect of depth and lime or phosphorus fertilizer applications on the soil solution chemistry of some New Zealand pastoral soils. Australian Journal of Agricultural Research 33: 461-476. 